\author{
Мария Владимировна Боброва \\ Институт лингвистических исследований РАН \\ Санкт-Петербург \\ ORCID: 0000-0001-9858-0573; e-mail: bomaripgu@yandex.ru
}

\title{
Наивная лексикография сельских жителей Пермского края (Россия)
}

\begin{abstract}
Реферат: В статье проанализированы образцы так называемой «наивной» лексикографии в Пермском крае (Россия). Выявлено, что 1) словарики краеведов-любителей различаются типологически (по отбору лексики и объему информации); 2) наивные лексикографы ориентированы главным образом на традиции, заложенные В.И. Далем; 3) основным принципом формирования словника является оппозитивность лексики; категориальной является оппозиция свой - чужой; 4) разнообразны функциональные установки авторов; 5) в методологических подходах отражается субъективность составителей, свойства их личности; 6) прагматически «наивные» словари ориентированы на коммуникативный акт с читателем. Сделанные наблюдения подтверждают существование «наивной» лексикографии как практической формы особого феномена - «наивной» лингвистики.
\end{abstract}

Ключевые слова: наивная лингвистика, наивная лексикография, Пермский край (Россия).

\begin{abstract}
Naive lexicography of the rural residents of the Perm region (Russia). This article analyses samples of the so-called "naive" lexicography in the Perm region (Russia). It was found that 1) dictionaries compiled by amateur local historians differ with respect to typology (the selection of vocabulary and the amount of information); 2) naive lexicographers are focused mainly on the traditions laid down by V.I. Dahl; 3) the main principle of forming of word lists in the dictionaries is the opposite nature of the vocabulary; the categorical opposition is between "own" and "other"; 4) the authors have adopted different functional settings; 5) the methodological approaches reflect the subjectivity of the compilers and their personality traits; 6) pragmatically "naive" dictionaries focus on a communicative act with the reader. These observations confirm the existence of "naive" lexicography as a practical form of a special Phenomenon: "naive" linguistics.
\end{abstract}

Keywords: naive linguistics, naive lexicography, Perm region (Russia).

Настоящая публикация лежит в русле исследований, посвященных феномену так называемой «наивной лингвистики» («вербализованных представлений метаязыковой рефлексии»; Бондаренко 2014в, 3) рядовых носителей языка, не являющихся профессиональными филологами, которую, по нашему мнению, следует отличать от «любительской лингвистики»: представители последней, имеющие опыт научных изысканий, но не в языковедческих областях, претендуют на научность, но лишь профанируют истинно научные изыскания (см. об этом, например, Зализняк 2000; Лебедева 2001). Фундаментальным исследованием в заявленном 
направлении стала коллективная монография Обыденное метаязыковое сознание: онтологические и гносеологические аспекты (2009-2012) в четырех частях. Сейчас изучаются, в частности, различные формы наивной лингвистики в коммуникативном пространстве сети Интернет (см., например Ващенко 2015; Ефремов 2014; 2015). В последние годы особенно возрос интерес к метаязыковой рефлексии диалектоносителей, главным образом к таким ее продуктам, как словари. И в этой связи необходимо упомянуть публикации Е.Л. Березович $(1997 ; 2003)$, А.Б. Мороза (2010), С.А. Мызникова (2007), С.М. Толстой (Березович, Толстая 2019), др.

Особенно значимы для настоящей публикации работы Е.Д. Бондаренко: диссертация Наивная лингвистика диалектоносителей: этносоџиолингвистический acnекm (Бондаренко 2014б, 2014в), статьи (Бондаренко 2014a, 2019а, 2019б), логичным продолжением которых стала работа по составлению свода любительских словарей говоров Русского Севера. Лингвистом тщательно проанализирована специфика словарей диалектоносителей, с его выводами в большой мере соотносимы наши заключения. И в настоящем случае целью своего выступления мы видим не столько изложение оригинальных теоретических положений, сколько уточнение уже озвученных наблюдений исследователей применительно к данным отдельного региона и ознакомление с новыми материалами - по пермским говорам, генетически восходящим к говорам Русского Севера и в значительной степени сохраняющим архаические черты.

В частности, мы бы хотели обратить внимание на следующий факт. Исследователи справедливо отмечают, что «наивнолингвистические» произведения неоднородны, и одна из важнейших причин этого - несходные социальные характеристики их составителей.

[Так,] среди авторов словарей присутствуют как «чистые» диалектоносители (люди, прожившие всю жизнь в одной местности, имеющие неполное образование и т. д.), так и «бывшие» диалектоносители (уехавшие из деревни в город, получившие образование и пр.); присутствует даже пример совмещения опыта диалектоносителя и опыта профессионального лингвиста» (Бондаренко 2014б, 162-163).

Кроме того, обратим внимание на эффект, открытый Т.И.Ерофеевой - основателем Пермской социолингвистической школы (см. Ерофеева 1995): с возрастом количество активно употребляемых диалектных слов возрастает, даже если под влиянием образования они уходили в пассивный запас, «забывались». В итоге, на наш взгляд, не вполне корректно говорить о «бывших» носителях говоров и одновременно использовать понятие «наивная лингвистика диалектоносителей». Дополнительный аргумент в пользу этого усматриваем еще и в том, что в качестве составителей словарей могут выступать не только местные жители, но и приезжие, нередко имеющие высшее образование, представители таких профессий, как учитель, библиотекарь, под., и потому особенно отчетливо ощущающие отличия своего языкового и речевого опыта от опыта окружающих людей. На этом основании предпочтительным видится более широкое понятие «наивная лингвистика сельских жителей». 
Толчком для написания настоящей статьи послужили материалы, обнаруженные во время экспедиций 2020 г. в Чайковский и Куединский районы Пермского края (Западный Урал, Россия). Полевые выезды 2020 года имели своей целью фиксацию узколокальных, прежде всего неофициальных ономастических данных (прозвищ и топонимов), что уже дало богатую почву для наблюдений над металингвистическими рефлексиями местных жителей. Но вместе с тем в ходе общения с информантами выяснилось, что даже в небольших населенных пунктах края очень активно ведется краеведческая работа, которую осуществляют учителя (филологи, историки, географы), библиотекари, рядовые жители сел и деревень (см. годы издания книг в разделе «Источники»). Итогом кропотливого труда энтузиастов стали многочисленные издания, весьма разнящиеся по объему (от 23 до полутысячи страниц), по охвату материалов (посвященные отдельному роду, истории населенного пункта, нескольких поселений, района), по жанру (мемуары, школьные рефераты, словари, а также компиляции, объединяющие документы, фотографии, в том числе из личных архивов, мемуары, статистические данные разных лет, газетные публикации, словари «трудных» слов, пр.), по методологическим подходам, по уровню исполнения.

Однако и ранее в ходе диалектологических экспедиций мы имели возможность ознакомиться с подобными работами, которые также привлечены в качестве материала для исследования в настоящей публикации: книги (МО, Гусева 2008), посвященные истории деревень Юрлинского района Коми-Пермяцкого округа Пермского края; топонимический словарик Верх-Язьвинского поселения Красновишерского района Пермского края (МРИ); копия рукописи (СИ), которая включает устаревшие и устаревающие слова говора д. Искор Чердынского района Пермского края, зафиксированные местным жителем Г.П.Пешехоновым (сделана в 2009 г. собирателем О.С.Тумановой); копия рукописи (ДЛЮ), которая включает диалектную лексику с. Юрла Коми-Пермяцкого округа Пермского края, зафиксированную сотрудниками Юрлинской сельской бибилиотеки (сделана в с. Юрле в 2013 г. собирателями И.И.Русиновой и Ю.А.Шкураток $)^{1}$.

Всего проанализированы словарики в 12 источниках.

Охарактеризуем выявленные в ходе экспедиции образцы «наивнолингвистической» литературы с опорой на анализ Е.Д.Бондаренко подобных лексикографических источников.

I. Краеведческие работы нередко содержат словарики: это либо собственно лексикографическое издание, либо одна из структурных частей публикации компилятивного характера. Словари разнообразны по содержанию (по принципу отбора языковых фактов): 1) синхронические: а) словарики местных слов, б) словарики «трудных» слов; 2) исторические словарики, отражающие лексикон определенного хронологического среза. Помимо этого, нам встретился специфичный вид встраивания лексикографической информации - в виде вкрапленной в основной текст справки о значении слова («Справка: Генеалогия - специальная историческая наука, занимается изучением и составлением родословных, выяснением

1 Копии рукописей сделаны с сохранением авторской орфографии и пунктуации. 
происхождения отдельных семей и лиц» - в разделе «Фамилия - это семья» [АЛВ, 178]).

Нам не встретилось ни одного списка (реестра, перечня) слов (такой способ передачи информации более свойствен устным ономастическим опросам и беседам, когда информанты лишь перечисляют известные им прозвища, топонимы, зоонимы без каких-либо комментариев).

Известные нам работы типологически различны. Словари отвечают нескольким жанрам.

А. Энциклопедические словари.

«Словарь-энциклопедия»² (МРИ, МСН) может включать разнообразную краеведческую информацию исторического, этнографического, лингвистического характера. Ср., например, словарную статью в топонимическом словарике:

«Мушники» (Тихий Ключ) - Исчез из списка населённых пунктов Фокинского поселения.

Это живописное место у тихо журчащей речушки. Жители Фок любят ездить сюда за клубникой. Когда-то здесь кипела жизнь, а сегодня лишь молчаливые тополя свидетельствуют об этом. Опять же в «Толковом словаре» В. Даля есть слово «мучник» или «мушник» - торговец мукой. Это слово вполне может иметь отношение к названию данного населённого пункта. По рассказам жительницы Фок Клячиной Елизаветы Филипповны (1936 года рождения) Мушники издавна славились хорошими урожаями зерновых и получаемой из них мукой. Даже в тяжёлые военные годы здесь пекли хлеб из настоящей муки. Если кто-то умирал в этой деревне, фокинская ребятня стремилась попасть на поминки, где им давали по куску настоящего хлеба.

Возможен ещё один вариант происхождения названия. «В этом месте летом водится много мошек (мушек)» $(\mathrm{MCH}, 11)$.

Б. Лингвистические словари.

1. «Список старинных слов» (ДЛЮ, Русин 2020, МО, Гусева 2008, СИ) составляется, чтобы зафиксировать архаичные элементы в речи местных жителей. Обычно представлен некоторым количеством лексем с толкованиями (чаще через синонимы литературного языка), ср.: «Вёснусь - прошлой весной... Витень кнут... Знатко - заметно... Кислица - щавель... Литовка - коса... Пельяны - пельмени... Шабур - предмет верхней одежды...» (Русин 2020, 292-295). Иногда такие списки дополняются иллюстрациями из живой речи, оформляются не списком, а в табличной форме: «Брандует / Брезгует / Пей, любая, не брандуй», «Ку́шки-па́шки / Второпях / Пригласили в гости, так я только Кушки-пашки налетела», «Ля́чкать / Лепетать, разговаривать / У нас ребенок-то уж лячкать начинает. Хватит попусту лячкать» (Гусева 2008, 77).

2. Некоторые словари совмещают признаки «словаря-воспоминания», «списка старинных слов», «словаря-шпаргалки» (АЯ, МРО, СК). Это работы, созданные местными энтузиастами, обычно учителями и библиотекарями, на какое-то время уезжавшими из родного села или деревни для получения образования. Очевидно, что более высокая степень овладения литературным языком в учебных заведениях

\footnotetext{
2 Жанры определены в терминологии Е.Д. Бондаренко.
} 
служит для них толчком к углублению метаязыковой рефлексии, к осознанию специфичности местного говора. Еще более ярко такую «самость» ощущают работники гуманитарной сферы, переехавшие из других населенных пунктов, районов края, из иных регионов. В своих трудах составители словарей опираются на учебные исследования школьников, опросы местных жителей преклонного возраста, записи (списки слов), которые делают жители среднего и пожилого возраста по просьбе собирателей, собственные воспоминания об особенностях речи старших родственников и соседей. Неоднородность информантов по социальным характеристикам, а также наличие нескольких авторов и обеспечивает неопределенность жанровой принадлежности конечного продукта.

3. Уникален единственный образец исторического словаря (БА), составитель которого (Н.С. Вайгандт) задалась целью отразить через лексику колорит жизни сельчан в период Великой Отечественной войны и объединила, в частности, словарные статьи ангина асептическая (септическая), божница, вероломный, изурочить (сглазить), лопоть (одежда), медунка (шмель), мутовка (приспособление для взбивания, изготовленное из вершинки молодой сосны), падера (буря с дождем, снегом), память, подвиг, садко (больно), страда, суррогат, суслон (укладка снопов), чай женить (заваривать чай второй раз), щёлок и др.

II. Нельзя не согласиться с Е.Д. Бондаренко в том, что авторы словарей

продолжают традиции любительской диалектной лексикографии XVIII-XIX вв., которой свойственна общая установка на меморативность и этнографизм; включение в словник экспрессивной лексики; «необычность» звучания как критерий попадания слова в словарь и др. (Бондаренко 2014в, 19).

Но мы не можем поддержать положение о том, что «заметна ориентация на современную научную и любительскую лексикографическую традицию» (Бондаренко 2014в, 19). По нашим наблюдениям, непреложным образцом лексикографического труда для «наивных» лингвистов остается словарь В.И. Даля. Об этом свидетельствуют уже списки использованной литературы (в том случае, когда они представлены авторами; ср., например, в МСН), а кроме того принципы построения словарной статьи: тяготение к толкованию через синонимы, факультативность иллюстративной части, толкование в том числе и отдельных (наиболее употребительных) форм слов, иногда игнорирование алфавитного способа организации словника. Не встретилось ни одной отсылки к наиболее авторитетному современному компендиуму Словарь русских народных говоров. В целом составители практически не ориентируются в научной литературе и современной лексикографической методологии, «отзвуки» которой усматриваются лишь в том, что предпочтение всё же отдается алфавитному выстраиванию словника, в исключительных случаях указано ударение, приводятся иллюстрации. Широкая опора делается на публикации местных краеведов без специального образования и научно-популярные книги (прежде всего на словарь Тимошка Пермитин из деревни Пермяки (Пермь, 1991), автор которого (Е.Н. Шумилов) - историк, что определило появление в словаре исторического контекста и некоторых неточностей в толковании происхождения имен собственных). Как следствие, для «наивной» лексикографии 
характерны терминологические недочеты и ошибки (ср., например, «географический» вместо «топонимический» словарь), игнорирование научной точки зрения в пользу народной (ложной) этимологии (см. выше словарную статью «Мушники» из МСН) и подобные факты.

3. Специфичны принципы отбора лексики для «наивных» словарей. Это могут быть тематические объединения: ср., например, словники в топонимических словариках (МРИ, МСН). Но принцип единообразия выдерживается лишь в отдельных изученных образцах, и даже в них крайне непоследовательно. Неслучайно появление таких своеобразных разновидностей, как «Алфавитный список непонятных слов» (даже не «словарь», МРО), «Словарь трудных слов» (СК) и просто «Словарь» (БА). Ср., в частности, словник в МРО, где удивительным образом сочетались диалектные слова, архаизмы, историзмы, юридические, медицинские, сельскохозяйственные, технические термины и общерусская лексика: акцепт, ватола, вексель, гороно, дупло, заготларек, индоссамент, конюховка, кошева, лутошка, маркетинг, маркетолог, метрика, МТС, осеменатор, полати, полог, портянка, онуча, районо, РВК, секвестр, стуловые тисы, тулуп, учительский институт, учительская семинария, членпайщик, чулан, шунтирование.

Безусловно права Е.Д. Бондаренко, которая обозначила в качестве главного принципа формирования словников в работах «наивных» лексикографов оппозитивность лексики на разнообразных основаниях. По нашим наблюдениям, такие основания вполне соотносимы с научными подходами к классификации слов: это время функционирования (старое - новое), место (местное (территориально ограниченное) - общерусское; в том числе место как социокультурный фактор: деревенское - городское), активность употребления (пассивный запас - активный запас), сфера употребления (общерусское - терминологическое). В качестве категориальной выступает оппозиция своего - чужого, с которыми начинают соотноситься и перечисленные элементы пар, например в таком виде: старое / местное / деревенское / свое - новое / городское / терминологическое / чужое.

Интересен с этой точки зрения словарик в (БА, 285-292), заявленный как такой, который отражает лексику определенного временного промежутка, т. е. сборник слов, объединенных по принципу хронологического единства (приводится с купюрами): айда к нам, айда-те, ак чё, ак чё ино, алашки, амбар, ангина асептическая (септическая), баня по-чёрному, бастриг, батюшка, бегать по улице, больно нужно, вероломный, голландка, горшовик, дресва, на закорках, колода, лапти, лучина, мамаша, отребье, памятник, патриотизм, перед печью, пистики, подписка, полати, суррогат, суслон, удёнкой, уполномоченный, учётчик, фитилёк, чугунок, шубенки, эвакуационный госпиталь, эвакогоспиталь.

При этом в зависимости от целей автора элементы оппозиций могут приобретать (для составителя «наивного» словаря!) функциональную неоднозначность, амбивалентность, что особенно свойственно лексике с точки зрения активности и сферы употребления слов: одна и та же лексика может толковаться или игнорироваться в словарях разных жанров и типов, хотя в конечном счете все такие лексикографические продукты нацелены на отражение местного колорита. Как следствие, соотносительность оппозитивных элементов варьируется: общерусское / свое - общерусское / чужое; новое / свое - новое / чужое; под. 
4. Цели составителей (функциональные установки) авторов «наивных» словарей разнообразны:

Основной является меморативная установка, «интенция памяти»... Кроме того, выделяются этнографические, энциклопедические, переводные, идеолого-популяризаторские интенции наивных лексикографов (Бондаренко 2014в, 20).

Можно добавить к этому списку историографические, философские (гносеологические) и психологические посылы: выражение патриотических чувств, увековечивание истории рода и малой родины, потребность в самореализации, активность жизненной позиции (особенно пенсионеров), даже поиск истины как смысл жизни и др. Ср. из предисловий:

Географические названия - творчество народа, драгоценные свидетели исторических событий, бережные хранители языковых древностей, объективные информаторы о географической среде. Географические названия появлялись не случайно. Они вобрали в себя исторические или географические реалии $(\mathrm{MCH}, 3)$.

Интерес к жизни наших предков, отражённой в народном словотворчестве, не угас. Он, как искорка от костра, сберегался в тайниках народной души... Вот и теперь с возрождением духовных сил народа - мы вольно или невольно ощущаем потребность в Истине. А Истина заложена не только в книгах Святого Благочестия, но и во всем том, что обращает нас к истокам простого народа, к его обычаям, традициям, к поэтическому языку, к чистому деревенскому слову. Хорошее образное слово, оберегаемое в пословице, поговорке и меткой фразе, как осколок забытого чуда, имя которому - народный язык (AЯ, 3).

Особенно волнует составителей словарей проблема связи поколений, преемственности традиций, ср.:

В быту еще встречаются слова и целые выражения, которые характерны для всего Пожинского поселения, но уже удивительны и непонятны молодежи... Родной язык глубокий, богатый, напевный, точный (Гусева 2008, 74).

Почувствовать атмосферу эпохи позволяют, конечно, прежде всего документы. Но и слова, простые слова - это тоже зеркало жизни... Что значили эти слова для наших предков? Что значат они для их потомков? В данный словарь включены слова и из повседневной жизни жителей наших деревень. Уж очень она отличалась от современной (БА, 285).

В связи с этим считаем необходимым указать на особую важность для составителей «наивных» словарей просветительских задач их деятельности, что настойчиво подчеркивается авторами в личных беседах с ними.

5. Безусловно, в принципах отбора и толкования слов отражаются личностные, социальные, социокультурные (в частности, религиозные), лингвистические характеристики составителей: уровень образования, степень владения литературным 
языком, степень знакомства с описываемыми реалиями, конфессиональная принадлежность и под. В итоге в «наивных» лингвистических трудах отражается не типическое в языке и «языковое сознание нерефлектирующего индивида» (Фрумкина 1989, 45), т. е. то, на что нацелена научная лексикография, а лингвистическое и экстралингвистическое сознание составителя ${ }^{3}$ Характерно, что обычно наиболее подробно разработаны те словарные статьи, которые отражают личные «открытия» их составителей. И можно обобщить: именно личностью составителя в конечном счете определяются принципы отбора, толкования и подачи языкового материала. Таким образом легко объяснить проникновение в словарь диалектных слов таких лексем, как батрак, безмен, борона, вица, вкупе, ВЛКСМ, генсек, дескать, доселе, кабала и под. (АЯ), а в «словарь эпохи»- диалектных, общерусских слов, терминов и др. (см. выше примеры из БА). Автор отбирает в итоге то, что является типичным (или нетипичным) для его собственного речевого поведения.

Ярким проявлением субъективного подхода «наивных» лексикографов считаем неожиданную для нас актуализацию такого фактора, как интересно - неинтересно, вербализуемого в устном общении с информантами и составителями словарей (Ну что тут у нас еще интересное?). Один из частных случаев реализации данной оппозиции усматриваем в паре экспрессивный - неэкспрессивный и в паре обычный - необычный (странный), что также может служить основанием для отбора слова для словаря или исключения его из словника ${ }^{4}$. Характерно, что этот же признак оказывается подчас решающим при сообщении информантом ономастических данных: называются интересные (выразительные, необычные, экзотические), с его точки зрения, онимы и игнорируются неинтересные (лишенные экспрессии, традиционные по форме) наименования. Так, в пос. Уральском Чайковского района все опрошенные вспомнили название горы Вшивой, хотя и не смогли объяснить его происхождение, но не все назвали единственный там Старый пруд. Или, в частности, информанты могут отметить: От фамилий-то много [прозвищ]; Это такие-то часто у нас используются, но привести лишь единичные примеры.

В наших материалах мы не обнаружили отмеченного Е.Д. Бондаренко противопоставления детское - взрослое, которое, очевидно, отражало индивидуальные интенции составителя конкретного словаря.

6. Вслед за Е.Д.Бондаренко отметим явную ориентацию «наивных» лексикографов на коммуникативный акт с читателем. Это, возможно, связано с просветительскими установками составителей и нередко выражается эксплицитно уже в предисловии, ср.:

Читатель, ты держишь в руках небольшой Словарик диалектных, забытых, вышедших из оборота речи слов, которые были в обиходе нашей местности... Надеемся, что наша

\footnotetext{
3 См.: лексикографическая концепция А. Вежбицкой (1996) о лексикографии как практике составления словарей, ориентированной на наивное восприятие.

4 Экспрессивность и необычность звукового оформления как критерий отбора слов также отмечается Е.Д. Бондаренко (2014б, 194).
} 
работа вызовет интерес людей разных возрастов: старшие вспомнят уже знакомое, молодёжь, наверное, удивится. И это хорошо! Может, зажгутся искорки в молодых душах... Лишь бы не одолело нас равнодушие! (АЯ, 3).

Проявляется такая установка в выборе заголовочного слова, в порядке следования толкуемых лексем, в способе толкования (Бондаренко 2014б, 20-21). Так, в самостоятельных статьях могут приводиться разные (не только начальные) формы прилагательных и местоимений: БаскОй - красивый; БассЕе, бАще - красивее; ЕвОйная - его (дочь); ЕЁшная - её (дочь); Ейный - её (сын) (АЯ, 5, 9). Коммуникативно ориентирован способ подачи глаголов, которые нередко предлагаются в той форме, которая является наиболее употребительной (актуальной) для носителей местного диалекта, ср.: Толмит - повторяет одно и то же (Русин 2020, 294); Напыряла - хотела сделать (МРИ, 77); Млит - мерещится, видится (БА, 289); Гимизят - шевелятся, их много (ДЛЮ); чикнул - слегка ударил (СИ); под.

В словариках, в которых слова не выстроены по алфавиту, можно обнаружить тематические и словообразовательные группировки слов, хотя возможно, что авторы записывали такие слова по ассоциации, по мере того, как лексика вспоминалась. Ср.: Бри́ньгать - звенеть (по струнам, по литовке). Бе́нгать - колотить. Бу́ли-ба́ли - булькать... Зы́бка - люлька. Зы́бать - качать (ДЛЮ).

Нацеленность на коммуникативный акт усматриваем и в специфике построения словарных статей, в тяготении к «энциклопедизации» толковательной части. Так, составитель «исторического» словарика продемонстрировал тенденцию к включению в словарные статьи разнообразных дополнительных сведений, ср.: Мост / Сени между избой и крыльцом - и: Назём / Навоз. Во время войны поля удобрялись органическими удобрениями: навозом и золой. Есть шутливая поговорка о некрасивой невесте: «Тот же назём, да издалека везём!» (БА, 289). Обратим при этом внимание на выбор лексики и стилистическое своеобразие: для толкования характерно научно-популярное изложение с предпочтением разговорных конструкций, иногда с вкраплением книжной или же, наоборот, сниженной (вплоть до нецензурной, даже в печатных изданиях) лексики в цитатах из живой речи.

Ориентация на коммуникативную прагматику усматривается также в том, что «наивные» словарики часто сопровождаются списками фразеологизмов, пословиц, паремий. Более того, иногда такие полилексемные, структурно сложные единицы внедряются в алфавитный список толкуемых слов.

Итак, в настоящее время в Пермском крае активно развивается «наивная» лексикография. В качестве составителей словарей выступают сельские жители, рядовые и имеющие образование выше среднего. Продукты лексикографирования обладают спецификой в сравнении с научными словарными трудами и отражают «наивные» метаязыковые рефлексии носителей местных диалектов. Вместе с тем особенности таких словарей оказываются типичными в сравнении со словарями, создаваемыми на других территориях, что позволяет говорить о сформированных тенденциях и традициях «наивной» лексикографической практики. Далее это дает возможность изучать на материале местных словарей специфику «наивного» лингвистического сознания. 
Особенно значимым представляется прагматический аспект изучения созданных непрофессионалами словарей: подобные труды, не отвечающие научным принципам по формальным критериям, дают богатейший материал для диалектной лексико- и фразеографии, социолингвистики, этнолингвистики, лингвопрагматики и других направлений современного отечественного языкознания. Перспективным видится объединение и опубликование всех имеющихся на данный момент образцов «наивной» лексикографии на единой платформе, прежде всего в электронном пополняемом компендиуме в сети Интернет.

\section{Источники}

АЛВ, Альняи - лебединая верность, ред.-сост. Н.С. Вайгандт, Ижевск, 2014.

АЯ, От «Авось» до «Яриться»: словарь говора села Степаново, деревень Митино и Коряки Чайковского района Пермского края, сост. Л.Е. Чудинова и др., Чайковский, 2019.

БА, Бормист, Альняш в тылу и на фронте, ред.-сост. Н.С. Вайгандт, Т.И. Кокорина, Чайковский, 2019.

Гусева К.П. (2008), Поклонись родному дому, Пермь.

ДЛЮ, Диалектная лексика с. Юрла Коми-Пермяцкого округа Пермского края: рукопись (копия), сост. работники Юрлинской сельской библиотеки, собир. И.И. Русинова, Ю.А. Шкураток, Юрла, 2013.

МО, Место отчее, сост. В.А. Кудымова и др., Пермь, 2011.

МРИ, Малой Родиньл история: словарь поселений Верхней Язьвы, сост. Т.А. Собянина, Е.А. Ванькова, Верх-Язьва, 2015.

МРО, Мы родом отсюда. Деревня Коряки глазами современников: документальное повествование, ред.-сост. Л.Е. Чуданова; лит. ред. Л.В. Оглезнева, Чайковский, 2015.

МСН, Милье сердиу названия: Географический словарь, сост. Н.Д. Глухова, Фоки, 2009.

Русин В.М. (2020), Земля куединская: история района от заселения до наших дней в рассказах, кн. I, Пермь.

СИ, Слова, вышедшие из обихода, собранные жителем д. Искор Чердынского района: рукопись (копия), собир. Г.П. Пешехонов, О.С. Туманова, Искор, 2009.

СК, Село на ключах: история села Степаново Чайковского района в документах, воспоминаниях и фотографиях. Документальное повествование в двух частях, Чайковский, 2018.

\section{Литература}

Березович Е.Л. [Berezovich E.L.] (1997), М.С. Устинова как языковая личность (к публикации авторского диалектного словаря) [M.S. Ustinova kak iazykovaia lichnost' (k publikatsii avtorskogo dialektnogo slovaria)], «Ежегодник Научно-исследовательского института русской культуры», 1995-1996, с. 128-137.

Березович Е.Л. [Berezovich E.L.] (2003), Диалектный словарь М.С. Устиновой (лексика диалекта глазами диалектоносителя) [Dialektnyi slovar' M.S. Ustinovoi (leksika dialekta 
glazami dialektonositelia)], «Актуальные проблемы полевой фольклористики», вып. 2, c. $267-277$.

Березович Е.Л., Толстая С.M. [Berezovich E.L., Tolstaia S.M.] (2019), Лексика Русского Севера: состояние и перспективы изучения [Leksika Russkogo Severa: sostoianie i perspektivy izucheniia], «Slovene», № 1, c. 486-525.

Бондаренко Е.Д. [Bondarenko E.D.] (2014a), Авторский словарь диалектоносителя: прагматический аспект [Avtorskii slovar' dialektonositelia: pragmaticheskii aspect], «Антропологический форум», № 21, с. 37-48.

Бондаренко Е.Д. [Bondarenko E.D.] (2014б), Наивная лингвистика диалектоносителей: этносоииолингвистический аспект, дис. ... канд. филол. наук [Naivnaia lingvistika dialektonositelei: etnosotsiolingvisticheskii aspect, dis. ... kand. filol. nauk], 10.02.01, Екатеринбург.

Бондаренко Е.Д. [Bondarenko E.D.] (2014в), Наивная лингвистика диалектоносителей: этносоииолингвистический аспект, автореф. дис. ... канд. филол. наук [Naivnaia lingvistika dialektonositelei: etnosotsiolingvisticheskii aspect, avtoref. dis. ... kand. filol. nauk], 10.02.01, Екатеринбург.

Бондаренко Е.Д. [Bondarenko E.D.] (2019a). К составлению свода любительских словарей говоров Русского Севера [K sostavleniiu svoda liubitel'skikh slovarei govorov Russkogo Severa], [в:] Славянские архаические ареаль в пространстве Европы, ред. С.М. Толстая, Москва, с. 354-384.

Бондаренко Е.Д. [Bondarenko E.D.] (2019б). Системные отношения в наивных словарях диалектоносителей [Sistemnye otnosheniia v naivnykh slovariakh dialektonositelei], [в:] Этнолингвистика. Ономастика. Этимология, ред. Е.Л.Березович, Екатеринбург, с. 45-48.

Ващенко Д.Ю. [Vashchenko D.Yu.] (2015), Интернет как новая перспективная форма существования диалектов [Internet kak novaia perspektivnaia forma sushchestvovaniia dialektov], «Исследования по славянской диалектологии», вып. 17: Судьбы славянских диалектов и перспективы славянской диалектологии в XXI веке, с. 197-204.

Вежбицкая А. [Vezhbitskaia А.] (1996). Язык. Культура. Познание [Iazyk. Kul'tura. Poznanie], Москва.

Ерофеева Т.И. [Erofeeva T.I.] (1995), Социолект: стратификаиионное исследование, дис. ... д. филол. н. [Sotsiolekt: stratifikatsionnoe issledovanie, dis. ... d. filol. nauk], 10.02.19, Санкт-Петербург.

Ефремов B.A. [Efremov V.A.] (2014), О новых формах наивной лингвистики в эпоху интернета [O novykh formakh naivnoi lingvistiki v epokhu interneta], «Антропологический форум», № 21, с. 74-81.

Ефремов В.A. [Efremov V.A.] (2015), Наивная лексикография как форма неографии: интернет-извод [Naivnaia leksikografiia kak forma neografii: internet-izvod], [в:] Неология и неография: современное состояние и перспективы, Санкт-Петербург, с. 28-29.

Зализняк А.A. [Zalizniak A.A.] (2000), Лингвистика по A.T. Фоменко [Lingvistika ро A.T. Fomenko], «Вопросы языкознания», № 6, с. 33-68.

Лебедева Н.Б. [Lebedeva N.B.] (2001), «Письменное просторечие» и гносеологическая толерантность [«Pis>mennoe prostorechie» i gnoseologicheskaia tolerantnost $]$ ], [в:] Лингвокультурологические проблемы толерантности, Екатеринбург, с. 244-247.

Мороз А.Б. [Moroz A.В.] (2010). «Старинные слова» в икольной тетрадке [«Starinnуе slova»v shkol'noi tetradke], «Живая старина», № 1, с. 19-21. 
Мызников C.A. [Myznikov S.A.] (2007). Авторские диалектные севернорусские словари [Avtorskie dialektnye severnorusskie slovari], «Рябининские чтения», с. 250-251.

Обыденное метаязыковое сознание: онтологические и гносеологические аспекты [Obydennое metaiazykovoe soznanie: ontologicheskie i gnoseologicheskie aspekty], ч. 1-4, ред. Н.Д. Голев, Кемерово - Барнаул, 2009-2012.

Фрумкина P.M. [Frumkina R.M.] (1989), Лингвист как познающзая личность [Lingvist kak poznaiushchaia lichnost'], [в:] Язык и когнитивная деятельность, Москва, с. 38-46. 